\title{
THE INFLUENCE OF THE APPLICATION OF QUANTUM LEARNING ASSISTED BY ISLAMIC CHARACTER MEDIA ON THE RESPONSIBILITY AND LEARNING OUTCOMES OF STUDENTS IN GRADE V SDN PRAMPELAN
}

\author{
Muhamad Afandi ${ }^{1}$, Yulina Ismiyanti ${ }^{2}$, Sri Wahyuningsih ${ }^{3}$ \\ ${ }^{1,2}$ Universitas Islam Sultan Agung, Semarang, Indonesia \\ ${ }^{3}$ Institut Agama Islam Negeri Kudus, Kudus, Indonesia \\ mafandi@unissula.ac.id, yulinaismiyanti@unissula.ac.id,wahyuningsih@iainkudus.ac.id
}

\begin{abstract}
The study aims at determining the effect of the implementation of the quantum learning model assisted by Islamic-character learning media on the responsibilities and learning outcomes of the fifth graders at Prampelan Elementary School. This research used is pre-experimental design. The results showed that there was an effect of learning responsibilities on the implementation of the quantum learning model assisted by Islamic character learning media influencing student learning outcomes, $51.8 \%$. Meanwhile, the remaining of learning outcomes, $48.2 \%$ of student learning outcomes could be explained by other variables outside this study. Based on the classical completeness test that students in Grade VA at SDN Prampelan with a quantum learning model assisted by Islamic learning media with a value of $\geq 65$ has reached $75 \%$.
\end{abstract}

Keywords: Quantum learning, media with Islamic character, responsibility and learning outcomes

\section{PENGARUH PENERAPAN MODEL QUANTUM LEARNING BERBANTUAN MEDIA PEMBELAJARAN BERKARAKTER ISLAMI TERHADAP TANGGUNG JAWAB DAN HASIL BELAJAR SISWA DI KELAS V SDN PRAMPELAN}

ABSTRAK

Tujuan penelitian ini adalah untuk mengetahui pengaruh penerapan model quantum learning berbantuan media pembelajaran berkarakter islami terhadap tanggung jawab dan hasil belajar siswa di kelas VA SDN prampelan. Jenis penelian yang digunakan adalah pre-experimental design. Hasil penelitian menunjukkan bahwa terdapat penganruh tanggung jawab belajar pada penerapan model quantum learning berbantuan media pembelajaran berkarakter Islami berpengaruh terhadap hasil belajar siswa sebesar $51.8 \%$ sedangkan sisanya sebesar $48.2 \%$ hasil belajar siswa dapat dijelaskan oleh variabel lain diluar penelitian ini. Berdasarkan uji ketuntasan klasikal bahwa siswa kelas VA SDN Prampelan dengan model quantum learning berbantuan media pembelajaran berkarakter islami yang mendapat nilai $\geq 65$ telah mencapai $75 \%$.

Kata Kunci: Quantum learning, media berkarakter islami, tanggung jawab dan hasil belajar

\begin{tabular}{|c|c|c|}
\hline Submitted & Accepted & Published \\
\hline 08 November 2019 & 06 Januari 2020 & 24 Januari 2020 \\
\hline
\end{tabular}

\begin{tabular}{|c|c|c|}
\hline Citation & : & 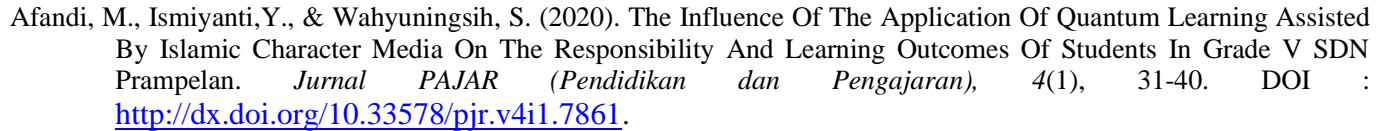 \\
\hline
\end{tabular}

\section{INTRODUCTION}

Education is an effort to empower people to become fully human beings so that they can actualize themselves, understand themselves and be able to support themselves, Achieving that there are all processes that must be passed, in the education process there are educators and educators and educators and educators (Sudarsana, 2016).
Learning which is the core of the education process must be designed by the teacher so that in its implementation it can deliver the students to achieve the specified learning objectives. Learning and learning are interrelated processes with the aim of obtaining and increasing a competency for every human being (Nurdyansyah \& Widodo, 2015). 
The teacher is one of the educational staff, responsible for the implementation and success of the learning process. The success or failure of the process is highly dependent on the facilities and quality of the teacher. For (Hasan, 2015). In line with the opinion of Zakaria (2016, p. 3) explains that teachers are the spearhead in the implementation of educational programs in schools. Therefore, no one doubts, how important is the role of the teacher for the success of efforts to improve and equalize the quality of education in schools. In this case, teachers are required to have academic qualifications, competencies, physical and spiritual educator certificates, and have the ability to realize national education goals.

Mulyasa (2015) teachers are educators who become figures, role models, identification for students, and their environment. Therefore teachers should have certain personal quality standards that include responsibility, authority, independence and discipline.

Primary school teachers are expected can choose the right learning model one of which is the quantum leming model is a learning strategy or method that makes students fun and motivates students to learn (Ahsin, 2016).

The role of Islamic learning media should be in the same direction and in line with the teachings set out in the Islamic religion. This is important so that students in particular, and Muslims in general can distinguish, measure, and weigh the value of information or knowledge that comes from instructional media that are prepared without Islamic values so that they are not misled. as contained. Allah says in QS. AlHujurat [49: 6] "O people of faith! If a wicked person comes to you with a story, then examine the truth so that you do not harm a people because of ignorance (carelessness) that ultimately you regret.

The act Based on observations in class $\mathrm{VA}$ and interviews with grade $\mathrm{V}$ teachers that students' learning responsibilities are still lacking, this is evidenced by the behavior of students that does not reflect the attitude of responsibility. The behavior is shown by the number of class $\mathrm{V}$ students who violate the rules set by the school such as students not wearing uniforms completely and true For example not wearing socks in accordance with uniforms nor wearing black shoes, not carrying out picket which is an obligation for every student Another example that shows a lack of responsibility in early students is when learning in class many students who do not listen to the delivery of material submitted by $h$ teacher and busy alone or talking with a peer when learning takes place this causes when the teacher gives students questions to do many students ask because they do not listen to the material that has been delivered by the teacher When the teaching and learning process the teacher also does not use instructional media resulting in students being less active and disciplined when following the teaching and learning process so that it affects the student learning outcomes are low.

Seeing the condition of the problem that is the lack of responsibility of students it will have an impact on student learning outcomes that are still low because responsibility will certainly affect student learning outcomes. Low learning outcomes are not only influenced by students' lack of responsibility, but there are also other factors that influence them such as the use of learning methods that only focus on the teacher and do not add methods or learning models that will make students more active or not easily bored in learning. Students perceive their learning as just so-so boring and also make students lazy to learn Class V learning materials which tend to force students to memorize the implementation of planning methods and teaching aids are needed so that students can achieve the Minimum Completeness Criteria.

The low learning outcomes among the student are evidenced by the score of Midterm Test showing that students of VA class SDN Prampelan 2017/2018 school year has not yet completed the Minimum Mastery Criteria determined by the school, 67. It is known from 44 students only 9 students who have already complete and 35 students are still incomplete. That means $20 \%$ completeness in learning. With the lowest score of 32 and the highest value of 88 By examining the data of student learning outcomes it can be concluded that student learning outcomes in learning are still low. 
From the problems faced by students in SDN Prampelan the lack of responsibility and student learning outcomes, a learning model and learning media are needed is appropriate in student-centered learning, and engages students in the learning process that is useful for effectively increasing student responsibility and learning outcomes to achieve learning goals. Thus a quantum leaming learning model is needed assisted by Islamic character learning media to achieve learning objectives.

Based on these descriptions, it shows that students at Prampelan Elementary School still have low learning outcomes. Besides, when students are learning, they often do not work on questions from the teacher and there is no desire

\section{LITERATURE REVIEW}

Quantum Leaning is a learning model that creates an effective learning environment, by using existing elements in students and their learning environment through interactions that occur in the classroom (Agusnanto, 2013, p. 4). Quantum lerning learning steps are known as the term Tandur which has the meaning of Growing is growing students 'interest and motivation, Natural is using students' initial knowledge to answer questions, Naming is giving names by providing keywords or showing concepts, Demonstration is students demonstrating teaching materials or opportunities practice, Repeat is repeating a lesson or concluding material, and Celebrate is giving recognition / appreciation to students (Sudarman \& Vahlia, 2016).

Quantum learning referred to in this study is the interaction between educators and students in the learning process at the elementary school which is carried out pleasantly and meaningfully so that it can achieve the goal of learning in accordance with the potential of students, thus the learning media that supports the media is needed as a component learning The use of media should be a part that should get the attention of learners in every learning activity.

Many types of media that can be chosen are developed and utilized in accordance with the time conditions of costs and learning goals that are climbed. Each type of media has certain to learn these results in less responsibility for learning, and also classroom teachers tend to be passive in learning. Variations in the use of media and learning props that will later make students happy in learning. And the media model and approach that teachers use are still monotonous. So the researcher raises the title "the effect of learning quantum learning model assisted with Islamic character learning media on the responsibilities and learning outcomes of students in grade V SDN Prampelan. The purpose of this study is to determine the effect of the application of quantum model assisted with Islamic character learning media on the responsibilities and student learning outcomes in Class V SDN Prampelan.

characteristics that we need to understand, so that we can choose the media that suits the needs and conditions that exist in the field (Falahudin, 2014). In line with (Susilana \& Riyana, 2008) that the media is a container of messages that the source of the message or its ignorant wants to be forwarded to the target or recipient of the message.

Learning media can be a vehicle for channeling messages and learning information, a well designed learning media will greatly help participants students in digesting and understanding subject matter (Muhson, 2010). In relation to the function of instructional media, the following things can be emphasized: (1) As a means of helping to create a more effective learning situation (2) As one component that is interconnected with other components in order to create the expected learning situation. (3) Speed up the learning process. (4) Improving the quality of teaching and learning process (5) Concretifying the abstract so that it can reduce the occurrence of verbalism. (Nurseto, 2011).

Islamic character learning media referred to in this study are learning media with Islamic values that are used by teachers in learning to integrate learning material in achieving learning objectives based on themes.

Learning is a relatively permanent change that occurs in all behaviors of an organism 
as a result of experience The ability to learn possessed by humans is a very basic provision. This ability to achieve higher cultural development (Toyiba, Fitriyani, 2016).

Learning outcomes are a process of changing intellectual abilities (cognitive), abilities of interest or emotions (affective) and fine and gross motor skills (psychomotor) in students. Changes in the ability of students in the learning process, especially in basic education units are expected in accordance with the stage of

\section{RESEARCH METHODS}

The research used was experimental research where experimental research contained treatment. The design applied in this study was Pre Experimental Designs. The researchers used the form of pre-experimental design design, namely one shot case test in experimental oneshot case test, there were groups given the treatment and then the results can be observed. The design in this study uses two classes. Then the class is given treatment $(\mathrm{X})$, the effect of the treatment (treatment) is an experimental class given a Quantum learning model assisted with Islamic character learning media.

This research was conducted on the fifth grade students of SDN Prampelan in the 2018/2019 school year to determine the experimental class using members of the VA class population of SDN Prampelan, with a total of 26 students and class VB of 28 students. Data collection techniques are the most important techniques in conducting research. Because basically research is conducted to obtain data. Then, there are several data collection techniques in research. This research used documentation test technique and interview.

The data analysis techniques in experiments can use statistical calculations. Preliminary data analysis was used so that researchers know the initial conditions of the sample class of data analyzed by the researcher, development, namely the operational stages of the congress (Afandi, Chamalah, \& Wardani, 2013).

Learning outcomes referred to in this study are that learning outcomes are a process of change in intellectual abilities (cognitive), in participants in education. Changes in the ability of students in the learning process, especially in basic education units are expected to be in accordance with the stage of development, namely in the operational stages of the congress in class V.

namely the data on the daily scores of sub-themes that have previously been tested by the class teacher. Data collection was carried out in a class that was sampled in this study. The data analysis can use the normality test. In this study, researchers used UI Liliefoers, this test can be used on discrete ie data in the form of distribution not in the form of intervals.

Analysis of the final data analyzed by researchers in the form of test scores Student learning outcomes Final data analysis was used to test from the hypothesis. After the sample is given treatment then the final test is then given to obtain data. Moreover, the researchers carried out the final data analysis.

The use of a nominality test was to find out the sample used is normal or abnormal distribution. This Hypothesis Test was conducted to find out that the influence of learning models aided by Islamic learning media with Islamic character toward students' learning outcomes and outcomes. As for looking for testing the difference in average results based on KKM on the value of students in the experimental class can use one-party $t$ test, $t$ test was used to test the hypothesis in one treatment research, $t$ test was used so that researchers know whether the average of the results of research conducted has met certain rules or not. 


\section{RESULTS AND DISCUSSION}

This research was conducted in VA students of Prampelan Elementary School as an experimental class with the treatment of the application of quantum learning models assisted with Islamic learning media, while as a control class that is VB SDN Prampelan students with lecture learning models. The purpose of this study was (1) to determine the effect of learning

\section{Preliminary Data Analysis}

responsibility on learning with a quantum learning model of Islamic learning media with student learning outcomes, (2) to find out whether the learning outcomes of VA class students in SDN Prampelan with quantum learming models assisted with learning media Islamic character can meet the KKM. The results of the study are as follows

Table 1. Preliminary Data Normality Tes Ressults

\begin{tabular}{lccl}
\hline Data & Kolmogorov-Smirnov Z & Sig. (2-tailed) & Conclusions \\
\hline Pretest A & 0.838 & 0.484 & Normal \\
Pretest B & 0.732 & 0.658 & Normal \\
\hline
\end{tabular}

Based on the table above it can be seen that the preliminary data (VA class) of the Kolmogorov smimov $\mathrm{Z}$ values are 0.838 and sig. (2-tailed) Of 0.484. and class VB class has Kolmogorov smirmov $\mathrm{Z}$ value of 0.732 and sig. (2-tailed) of 0.658. Because the value of sig. (2- tailed) $>0.05$ for both VA and VB class pretests, then $H_{0}$ is accepted. So the data is normally distributed.

\section{Final Analysis Data}

a. Normality Test

Table 2. Final Data Normality Test Results

\begin{tabular}{lccl}
\hline Data & Kolmogorov-Smirnov Z & Sig. (2-tailed) & Conclusions \\
\hline Posttest A & 1.159 & 0.136 & Normal \\
Posttest B & 0.842 & 0.478 & Normal \\
\hline
\end{tabular}

Based on the table above it can be seen that the final data (posttest) of the VA class value of Kolmogorov smirmov Z is 1.159 and sig. (2tailed) of 0.136. and VB class has Kolmogorov smimov $\mathrm{Z}$ value of 0.842 and sig. (2-tailed) of
0.478. Because the value of sig. (2-tailed) $>0.05$ in both VA and VB class posttests, then $H_{0}$ is accepted. So the data are normally distributed Homogeneity Test.

Table 3. Homogeneity Test Results

\begin{tabular}{llll}
\hline Data & F hitung & Sig. (2-tailed) & Conclusion \\
\hline Posttest & 1.56 & 0.217 & Homogen \\
\hline
\end{tabular}

Based on the table above it can be seen that the calculated $F$ value of 1.56 and the value of sig. (2- tailed) of 0.217. Because the value of sig. $>0.05$, then $H_{0}$ is accepted. So it can be concluded that the VA class posttest data with the
VB class posttest data come from the same population (homogeneous data).

c. Hypothesis Testing

1) Hypothesis Test 1 
Hypothesis 1 test is a hypothesis test to determine the effect of the attitude of responsibility towards learning outcomes at SDN Prampelan with a quantum learning model assisted with Islamic character learning media. a Hypothesis Test

Hypothesis

$H_{0}$ : There is no influence of learning responsibility on learning with a quantum learning model assisted with Islamic character learning media on student learning outcomes.

$H_{1}$ : There is an influence of learning responsibility on learning with a quantum learning model assisted with Islamic character learning media on student learning outcomes.

Criteria for measurement

Accept $H_{0}$ if sig value $>0.05$.

Output results

Table 4. Anova ${ }^{a}$

\begin{tabular}{cccccc}
\hline Model & Sum Squares & df & Mean Square & F & Sig. \\
\hline Regression & 1248.515 & 1 & 1248.515 & 25.828 & $.000^{\text {b }}$ \\
Residual & 1160.138 & 24 & 48.339 & & \\
Total & 2408.654 & 25 & & & \\
\hline
\end{tabular}

a. Dependent Variable: $\mathrm{Y}$

b. Predictors: (Contant), $\mathrm{X}$

Interpretation

Based on the results of the above output it is known that the sig value of 0.000 . Because $0.000<0.05$ then $H_{0}$ denotes that there is an influence of learning responsibility on learning with quantum leaning models assisted with Islamic character learning media on student learning outcomes 1 correlation coefficient. a. Coefficien of Determination $\left(R^{2}\right)$ and correlation coefficient $(R)$

The coefficient of determination $\left(R^{2}\right)$ test is carried out to measure how much the independent variables in the research model are able to explain the dependent variable.

Table 5. Model Summary

\begin{tabular}{ccccc}
\hline Model & R & R Square & $\begin{array}{c}\text { Adjusted R } \\
\text { Square }\end{array}$ & $\begin{array}{c}\text { Std. Error of the } \\
\text { Estimete }\end{array}$ \\
\hline 1 & $.720^{\mathrm{a}}$ & .518 & .498 & 6.95263 \\
\hline
\end{tabular}

Based on the table above the coefficient of determination test $\left(R^{2}\right)$ can be seen by looking at the value generated in the $\mathrm{R}$ Square column that is equal to 0.518 . From these results it can be concluded that the learning responsibility (X) on learning with a quantum learning model assisted by Islamic character learning media influences student learning outcomes (Y) by $51.8 \%$ while the remaining $48.2 \%$ student learning outcomes can be explained by Other variables outside this study. In column $\mathrm{R}$ generated a value of 0.720 which shows that the relationship between learning responsibilities in learning with quantum learning models assisted with Islamic character learning media with strong and unidirectional student learning outcomes.

b. Test the significance of the Regression equation 
Tabel 6. Coeffients ${ }^{\mathrm{a}}$

\begin{tabular}{|c|c|c|c|c|c|}
\hline \multirow{2}{*}{ Model } & \multicolumn{2}{|c|}{ Unstandardized Coefficients } & standardized & \multirow{2}{*}{ Sig. } & \\
\cline { 2 - 4 } & $\mathbf{B}$ & Std. Error & Beta & & \\
\hline Contant) & $\mathbf{3 3 . 4 0 8}$ & $\mathbf{7 . 7 3 7}$ & & $\mathbf{4 . 3 1 8}$ & $\mathbf{. 0 0 0}$ \\
X & .912 & .179 & .720 & $\mathbf{5 . 0 8 2}$ & $\mathbf{. 0 0 0}$ \\
\hline
\end{tabular}

The regression equation in this study can be formulated as follows :

$Y=33,408+0,912 X$

Where;

$Y \quad$ : Learning outcomes

$X \quad$ : Attitude of responsibility

The coefficient of variable $\mathrm{X}$ is 0.912 .

Every $1 \%$ increase in the variable of responsibility attitude, student learning outcomes also increased by 0.912 . The regression coefficient $\mathrm{X}$ to $\mathrm{Y}$ has a positive value, this means that there is a positive relationship between the variable attitude of responsibility with learning outcomes.

\section{2) Hypothesis test 2}

Hypothesis 2 test is a hypothesis test to find out the average student learning outcomes in SDN Prampelan with a quantum learning model assisted with Islamic character learning media that can meet the KKM. Experimental class students who have learned learning outcomes have met the Minimum Mastery Criteria of 65 in accordance with the KKM that has been determined in class $\mathrm{V}$ SDN Prampelan, the hypothesis is as follows:

H0 : $\mu_{0} \leq 65$, (Average learning outcomes of Prampelan Elementary School students with quantum learning models assisted with Islamic character learning media $\leq 65$ )

$\mathrm{Ha}: \mu_{0}>65$ (Average learning outcomes of Prampelan Elementary School students with quantum learning models assisted with Islamic character learning media > 65)

As for looking for testing the difference in average results based on KKM on the value of students in the experimental class can use oneparty $t$ test. The following is the calculation of the test $\mathrm{t}$ :

$t=\frac{\bar{x}-\mu_{0}}{s / \sqrt{n}}$ $t=\frac{72.12-65}{\frac{9,816}{\sqrt{26}}}$

$t=3.396$

Based on the calculation it is known that the calculated value $t_{\text {hitung }}$ is 3.396 and the value of $t_{\text {tabel }}$ with $\mathrm{dk}=(\mathrm{n}-1)$ and a $5 \%$ significance level is 2.06. So the value $t_{\text {hitung }}>$ $t_{\text {tabel }}$, then: then Ho is rejected. So it can be concluded that the average learning outcomes of Prampelan elementary school students with a quantum learming model assisted with learning media with Islamic character $>65$

3) Hypothesis test 3

Test Hypothesis 3 is a classical completeness test used to test the proportion of one party. The statistical hypothesis is as follows. $H_{0}: \pi \geq \pi_{0}$ (The proportion of students who get a score of $\geq 65$ has reached $75 \%$ )

$H_{1}: \pi<\pi_{0}$ (The proportion of students who get a score of $\geq 65$ has reached $75 \%$ )

where $\pi_{0}$ is the completeness criteria of learning outcomes of the experimental test class. The statistical test formula used is as follows:

$$
\begin{aligned}
& z=\frac{\frac{x}{n}-\pi_{0}}{\sqrt{\frac{\pi_{0}\left(1-\pi_{0}\right)}{n}}} \\
& z=\frac{\frac{21}{26}-0,75}{\sqrt{\frac{0.75 * 0.25}{26}}} \\
& z=0.679
\end{aligned}
$$

Based on the above calculation results can be obtained value $z_{\text {hitung }}$ of 0.679 . Furthermore these results are compared with the value of table $\mathrm{Z}$ using the real level $\alpha=0.05$ which is worth 1.96. So $Z_{\text {hitung }}>Z_{(0,5-\alpha)}$, then $H_{0}$ is accepted. So the proportion of students of Prampelan 
Elementary School with a quantum learning model assisted by Islamic character learning media that scored $\geq 65$ has reached 75

\section{4) Hypothesis test 4}

Hypothesis 4 test was conducted to determine whether there are differences in the average pretest and posttest of students with quantum learning models assisted with Islamic character learning media. Therefore a two-tailed ttest is used, the statistical hypothesis is as follows.
$\mathrm{H}_{0}: \mu_{1}=\mu_{2}$, (There is no significant difference in the average pretest and posttest of students with learning models assisted with Islamic character learning media)

$\mathrm{H}_{1}: \mu_{1} \neq \mu_{2}$, (There is a significant difference in the average pretest and posttest of students with learning models assisted with Islamic character learning media)

The test was carried out using SPSS 20 by using paired sample $t$ test. Here are the results of the test.

Table 7. Paired Sample T-test Test Results

\begin{tabular}{llll}
\hline Data & t hitung & Sig. (2-tailed) & Conclusion \\
\hline pre-post A & $-15,740$ & 0,000 & There is a significant difference
\end{tabular}

Based on the results of the Paired Sample $\mathrm{T}$-test it can be seen that the calculated $\mathrm{t}$ value is 15.740 and the value of sig, (2-tailed) is 0.000 . Because the value of sig. $<0.05$, then $H_{0}$ is rejected. So it can be concluded that there are significant differences in the average pretest and posttest of students with quantum learning models assisted with Islamic character learning media.

\section{5) Hypothesis test 5}

This test is conducted to find out whether there are differences in the average learning outcomes of students with quantum leaning models assisted by Islamic learning media with student learning outcomes with lecture learning models, and which is better learning outcomes between the classes. Therefore one party's t test was used. The statistical hypothesis is as follows.

$\mathrm{H}_{0}: \mu_{1} \leq \mu_{2}$, ((the average student learning outcomes with a quantum learming model aided by instructional media with Islamic characters less than or equal to class students with lecture learning).

$\mathrm{H}_{1}: \mu_{1}>\mu_{2}$, (the average student learning outcomes with a quantum learming model aided by Islamic learning media characterized more than students with lecture learning).

The test was carried out using SPSS 20 by using the independent sample $t$ test. Here are the results of the test.

Table 8. Paired Sample T-test Test Results

\begin{tabular}{lrll}
\hline Data & t hitung & Sig. (2-tailed) & Conclusion \\
\hline Post A-post B & 4,607 & 0,000 & There is a significant difference \\
\hline
\end{tabular}

Based on the table above it can be seen that the calculated $\mathrm{t}$ value is 4.607 and the sig value. ( 2 tailed) of 0,000 . Because the value of sig. $<0.05$, then $H_{0}$ is rejected. So there is a significant difference in the average student learning outcomes with the quantum learning model assisted by Islamic character learning media and students with lecture learning. To find out which class is superior is to look at the average posttest. Based on descriptive data, it can be obtained the average value of the VA class of 72.12 and the average VB class of 57.68 so that the VA class is superior to the VB class. So it can be concluded that the average student learning 
outcomes with the quantum learning model is assisted by Islamic character learning media more

\section{CONCLUSIONS AND RECOMMENDATIONS}

There is an influence of the attitude of responsibility towards learning outcomes in SDN Prampelan with a quantum learning model assisted with Islamic character learning media. It is known that the sig value is 0,000 . Because 0.0000 .05 then reject $H_{0}$ which means that there is an influence of learning responsibility on learning with a quantum learning model that is assisted by Islamic character learning media on student learning outcomes. Based on the coefficient of determination test $\left(R^{2}\right)$ can be seen by looking at the value generated at $\mathrm{R}$ Square vaitu of 0.518 . From these results it can be concluded that the learning responsibility $(\mathrm{X})$ on learning with quantum learming models assisted by Islamic learning media has an effect on student learning outcomes (Y) of $51.8 \%$ while the remaining $48.2 \%$ of student learning outcomes can be explained by Other variables outside this study. In R Square a score of 0.720 is produced which indicates that the relationship between responsibility for learning in learning with Islamic character models with strong and unidirectional student learning outcomes. The regression equation in this study the coefficient of variable $\mathrm{X}$ is 0.912 . Every $1 \%$ increase in the variable of responsibility attitude, student learning outcomes also increased by 0.912 . The regression coefficient $\mathrm{X}$ to $\mathrm{Y}$ is positive, this means that there is a positive relationship between the variables of responsibility and learning outcomes of learning quantum-assisted learning media.

\section{DAFTAR PUSTAKA}

Afandi, M., Chamalah, E., \& Wardani, O. P. (2013). Model dan Metode Pembelajaran di Sekolah. In Diakses dari http://www. Fcyber. unissula. ac. id\% 2Fjournal\% 2Fdosen\% 2Fpublikasi\% 2F2 (Vol. 11313015). Semarang: Unissula Press. than students with lecture learning.

There is a difference in the average student learning outcomes with the quantum learning model assisted by Islamic character learning media with student learning outcomes with the lecture learning model, that the average value of the VA class is 72.12 and the average VB class is 57.68 so that the VA class superior to VB class. So it can be concluded that the average student learning outcomes with the quantum learning model is assisted by Islamic character learning media more than students with lecture learning.

Learning in Elementary School Grade V with a quantum learming model assisted by Islamic learning media is crucial in determining the responsibilities and student learning outcomes, so it is expected for teachers to use the quantum learning model by choosing learning media to be in accordance with their development, because fifth grade students have entered into concrete operational stage where students think according to real experiences or concrete objects, then in choosing media must be in accordance with events experienced by students or according to students' intellectual development. The school is expected to be able to facilitate facilities and infrastructure that can support the learning process that is fun for students. For further researchers, it is expected to be able to research using learning models that are in accordance with and use Islamic learning media on themes and other sub themes that have been determined so as to achieve the learning objectives.

Agusnanto. (2013). Penerapan model pembelajaran. Jurnal PGSD Universitas Surabaya, 01( 0), 0-216.

Ahsin, M. N. (2016). Peningkatan Keterampilan Menulis Karangan Narasi Dengan Menggunakan Media Audiovisual Dan Metode Quantum Learning. Refleksi 
Edukatika, $\quad 6(2), \quad 158-171$.
https://doi.org/10.24176/re.v6i2.607

Falahudin, I. (2014). Pemanfaatan Media dalam Pembelajaran. Lingkar Widyawiswara, 1(Desember), 104-117.

Hasan, H. (2015). Kendala yang dihadapi Guru dalam Proses Belajar Mengajar Matematika di SD Negeri Gani Kabupaten Aceh Besar. Jurnal Pesona Dasar, 1(4), 40-51.

Muhson, A. (2010). Pengembangan Media Pembelajaran Berbasis Teknologi Informasi. Pendidikan Akuntansi Indonesia, $\operatorname{VIII}(2), 1-10$.

Mulyasa, E. (2015). Menjadi Guru Profesional. Bandung: Rosdakarya.

Nurdyansyah, \& Widodo, A. (2015). Inovasi Teknologi Pembelajaran. Sidoarjo: Nizamia Learning Center. Retrieved from http://www.ghbook.ir/index.php?name=

فر هنى نوين هائioption=com_dbook\&task=readonline \&book_id $=13650 \&$ page $=73 \&$ chkhashk $=\mathrm{E}$ D9C9491B4\&Itemid=218\&lang=fa\&tmpl= component

Nurseto, T. (2011). Membuat Media Pembelajaran yang Menarik. Ekonomi \& Pendidikan, 8, 19-35. https://doi.org/media pembelajaran

Sudarman, S. W., \& Vahlia, I. (2016). Efektifitas Penggunaan Metode Pembelajaran Quantum Learning terhadap Kemampuan
Pemahaman Konsep Matematis Mahasiswa Satrio. Al-Jabar: Jurnal Pendidikan Matematika, $\quad 7(2), \quad$ 275-282. https://doi.org/https://doi.org/10.24042/ajp m.v7i2.42

Sudarsana, I. K. (2016). Pemikiran Tokoh Pendidikan Dalam Buku Lifelong Learning: Policies, Practices, And Programs (Perspektif Peningkatan Mutu Pendidikan di Indonesia). Jurnal Penjaminan Mutu, 2(2),

44. https://doi.org/10.25078/jpm.v2i2.71

Susilana, R., \& Riyana, C. (2008). Media pembelajaran: hakikat, pengembangan, pemanfaatan, dan penilaian. CV. Wacana Prima, 2008. Wacana Prima. Bandung: Wacana Prima. Retrieved from https://books.google.co.id/books?id=ku0_D wAAQBAJ\&printsec $=$ frontcover\&source $=$ gbs_ge_summary_r\&cad $=0 \# \mathrm{v}=$ onepage $\& \mathrm{q}$ $\& \mathrm{f}=$ false

Toyiba, F. N. (2016). Pengaruh Strategi pembelajaran Aktif Terhadap hasil belajar pada Madrasah Ibtidaiyah. Pendidikan Guru Madrasah Ibtidaiyah, 1(2), 929-930.

Zakaria, T. R. (2016). Pembaharuan Mutu Guru. Buletin BSNP (Vol. XI). Jakarta. Retrieved from http://bsnp-indonesia.org/wpcontent/uploads/2016/10/Buletin-BSNPEdisi-3-2016.pdf 